\title{
ANALISIS STRATEGI PEMASARAN UMKM DI ERA 4.0
}

\author{
Mashuri \\ Sekolah Tinggi Ilmu Ekonomi (STIE) Syariah Bengkalis \\ mashurymr@gmail.com
}

\begin{abstract}
This research is literature research, aimed at knowing how to analyze the marketing strategies used by micro, small and medium businesses in the digital age 4.0. The results of the analysis in this study found that micro, small and medium enterprises in Indonesia are still low when compared to other countries. The contribution of the micro, small and medium business sector to national exports was $15.80 \%$ lower than Malaysia 19.00\%, Sri Lanka 20.00\%. One contributing factor to the low contribution rate is the lack of potential use of existing resources by micro, small and medium business actors such as the use of mobile social media. Through the digital era 4.0 the marketing system of the micro, small and medium business sector is expected to utilize the maximum potential so that it can grow inclusive and sustainably.
\end{abstract}

Keywords: Marketing Strategy, UMKM, Era 4.0.

\begin{abstract}
ABSTRAK
Penelitian ini adalah penelitian literatur, bertujuan mengetahui bagaimana analisi strategi pemasaran yang digunakan oleh usaha mikro, kecil dan menengah (UMKM) di era digital 4.0. Hasil analisis dalam penelitian ini mendapatkan bahwa usaha mikro, kecil dan menengah di Indonesia masih rendah bila dibandingkan dengan negara lain. Kontribusi sektor usaha mikro, kecil dan menengah terhadap ekspor nasional sebesar $15.80 \%$ lebih rendah dari Malaysia $19.00 \%$, Sri Lanka $20.00 \%$. Salah satu faktor penyebab dari rendahnya angka kontribusi adalah minimnya penggunaan potensi sumber daya yang ada oleh pelaku usaha mikro, kecil dan menengah seperti penggunaan media sosial mobile. Melalui era digital 4.0 sistem pemasaran sektor usaha mikro, kecil dan menengah diharapkan dapat memanfaatkan potensi yang maksimal sehingga mampu tumbuh inklusif dan berkelanjutan.
\end{abstract}

Kata kunci: Strategi Pemasaran, UMKM, Era 4.0.

\section{PENDAHULUAN}

Dalam dunia bisnis strategi pemasaran bagaikan sebuah jantung untuk kelancaran sebuah usaha. Arus globalisasi sudah tidak terbendung lagi masuk keberbagai bisnis usaha. Era revolusi merupakan fenomena yang mutlak dan tidak dapat dihindari. Kini sudah saatnya kegiatan bisnis memerlukan strategi yang mumpuni dan mampu melakukan transformasi dan inovasi untuk menghadapinya agar bisnis tersebut tidak tergilas oleh zaman. 
Strategi pemasaran diperlukan pada berbagai lini produk dan jasa. Strategi pemasaran produk atau barang berbeda dengan strategi pemasaran jasa. Bisnis jasa lebih cenderung memberikan pelayanan kepada konsumen yang diukur dari tingkat kepuasan konsumen yang diperolehnya. Dalam era yang serba kempetitif ini berbagai perusahaan sudah mulai melakukan inovasi terhadap berbagai strategi pemasaran. Untuk produk yang bersifat jasa penggunaan manajemen pemasaran yang konvensional sudah tidak tepat lagi karena orientasi pemasaran dinilai telah mengalami perubahan yang awalnya hanya orientasi penjualan menjadi orientasi nilai tambah pelanggan. Orientasi bisnis bukan hanya mencari laba melalui penciptaan pelanggan namun juga berprinsipkan relationship marketing \& customer relation management yang bertujuan mendapatkan laba untuk jangka panjang melalui kepuasan pelanggan. Sehingga disini konsumen sebagai konsumsi akhir dapat diartikan kepuasan keinginan dan hasrat konsumen yang akan dimiliki.

Mata rantai setiap pembelian produk memerlukan jasa, sehingga setiap produk yang dibeli oleh konsumen harga didalam produk tersebut sudah termasuk harga jasa. Fandy Tjiptono dan Gregorius Chandra dalam bukunya Service, Quality \& Satisfaction mengemukakan bahwa sektor jasa berperan signifikan dalam perekonomian dunia. Di negara maju seperti Amerika Serikat, sektor jasa berkontribusi terhadap sekitar 80\% Produk Domestik Bruto (PDB) dan lebih dari $50 \%$ total pengeluaran konsumen dibelanjakan untuk jasa (Etzel, Walker dan Stanton 2001). Ini dapat diartikan bahwa setiap produk memerlukan jasa untuk kesinambungan bisnis karena jasa adalah bagian dari produk. Selain itu, jasa juga merupakan salah satu sumber lapangan kerja. Pekerjaan dalam sektor jasa di Amerika Serikat diperkirakan mencapai $79 \%$ dari total lapangan kerja dan diprediksi akan menyediakan sekitar $90 \%$ dari keseluruhan lapangan kerja baru pada dekade awal abad 21 (Kotler 2001).

Penciptaan nilai pelanggan untuk memenuhi keinginan pelanggan diperlukan berbagai kombinasi dari strategi pemasaran yang ada. Pada era industri 4.0 atau lebih dikenal dengan era digital, sangat mudah dijumpai bagaimana bisnis kini memenuhi keinginan pelanggan melalui penggunaan jasa yang ada. Jika ditelusuri bahwa para ibu rumah tangga bisa melakukan bisnis online dari rumah hanya menggunakan paket data dan android (gadget). Ini dapat dikatakan bahwa bisnis jasa dapat memudahkan keinginan pelanggan dengan maksimal. Keadaan ini tentu sudah menjadi bagian dari strategi melalui jasa digital yang diberikan oleh sistem. Sistem jasa ini juga berfungsi untuk memendekkan mata rantai penjualan sehingga harga menjadi lebih terjangkau.

Berdasarkan paparan diatas maka penulis akan mengulas lebih jauh tentang strategi yang digunakan oleh pemasar untuk memaksimalkan barang dagangannya melalui sistem digital di era 4.0. Strategi pemasaran yang dimaksud adalah memasarkan produk UMKM Indonesia. Tulisan ini diharapkan dapat memberikan kontribusi kepada pelaku bisnis dalam meningkatkan pendapatannya melalui barang dan jasa yang ditawarkan kepada pelanggannya. 


\section{LITERATUR REVIEW}

\section{Pemasaran}

Menurut Kotler (2001) bahwa pemasaran adalah proses sosial dan managerial dimana perorangan dan kelompok mendapatkan kebutuhan mereka dengan menciptakan, penawaran produk yang bernilai masing-masing. Inti dari kegiatan pemasaran adalah untuk mengembangkan suatu produk, distribusi, komunikasi, penetapan harga dan pelayanan. Kotler (2001) juga mengatakan bahwa didalam pemasaran terdapat bauran pemasaran. Bauran pemasaran ialah serangkaian variabel pemasaran terkendali yang dipakai oleh perusahaan untuk menghasilkan tanggapan yang dikehendaki perusahaan dari pasar sasarannya, bauran pemasaran terdiri dari segala hal yang bisa dilakukan perusahaan untuk mempengaruhi permintaan atas produknya.

Kemudian Kotler (2005) menyebutkan bahwa strategi pemasaran adalah suatu mindset pemasaran yang akan digunakan untuk mencapai tujuan pemasaran, dimana di dalamnya terdapat strategi rinci mengenai pasar sasaran, penetapan posisi, bauran pemasaran dan budget untuk pemasaran. Kotler (2008) mendefinisikan alat pemasaran kedalam $7 \mathrm{P}$ atau sering disebut marketing mix yaitu: produk, tempat, harga, promosi, orang, bukti fisik dan proses.

\section{Usaha Mikro, Kecil dan Menengah (UMKM)}

Definisi UMKM diatur dalam Undang-Undang Republik Indonesia No. 20 Tahun 2008 tentang UMKM. Pasal 1 dari UU terebut, dinyatakan bahwa Usaha mikro adalah usaha produktif milik orang perorangan dan/atau badan usaha perorangan yang memiliki kriteria usaha mikro sebagaimana diatur dalam UU tersebut. Usaha kecil adalah usaha ekonomi produktif yang berdiri sendiri, yang dilakukan oleh orang perorangan atau badan usaha yang buka merupakan anak perusahan atau bukan anak cabang yang dimiliki, dikuasai atau menjadi bagian, baik langsung maupun tidak langsung, dari usaha menengah atau usaha besar yang memenuhi kriteria usaha kecil sebagaimana dimaksud dalam UU tersebut. Sedangkan usaha mikro adalah usaha ekonomi produktif yang berdiri sendiri yang dilakukan oleh perorangan atau badan usaha yang bukan merupakan anak perusahaan atau bukan cabang perusahaan yang dimiliki, dikuasai, atau menjadi bagian baik langsung maupun tidak langsung, dari usaha mikro, usaha kecil atau usaha besar yang memenuhi kriteria usaha mikro sebagaimana dimaksud dalam UU tersebut (Tambunan 2009, 16).

Di dalam Undang-Undang tersebut, kriteria yang digunakan untuk mendefinisikan UMKM seperti yang tercantum dalam Pasal 6 adalah nilai kekayaan bersih atau nilai aset tidak termasuk tanah dan bangunan tempat usaha, atau hasil penjualan tahunan. Usaha mikro adalah unit usaha yang memiliki aset paling banyak Rp.50 juta tidak termasuk tanah dan bangunan tempat usaha dengan hasil penjualan tahunan paling besar Rp.300 juta. Usaha kecil dengan nilai aset lebih dari Rp. 50 juta sampai dengan paling banyak Rp.500 juta tidak termasuk tanah dan bangunan tempat usaha memiliki hasil penjualan tahunan lebih dari Rp.300 juta hingga maksimum Rp.2,5 milyar. Usaha menengah adalah perusahaan dengan milai kekayaan bersih lebih dari Rp.500 juta hingga paling banyak Rp.100 milyar hasil penjualan tahunan di atas Rp.2,5 milyar sampai paling tinggi Rp.50 milyar (UURI 2008). 


\section{Era 4.0}

Era 4.0 sering disebut dengan era Industri 4.0, dalam Prasetyo $(2018,19)$ menyebutkan bahwa definisi mengenai Industri 4.0 beragam karena masih dalam tahap penelitian dan pengembangan. Kanselir Jerman, Angela Merkel (2014) berpendapat bahwa Industri 4.0 adalah transformasi komprehensif dari keseluruhan aspek produksi di industri melalui penggabungan teknologi digital dan internet dengan industri konvensional. Schlechtendahl dkk (2015) menekankan definisi kepada unsur kecepatan dari ketersediaan informasi, yaitu sebuah lingkungan industri di mana seluruh entitasnya selalu terhubung dan mampu berbagi informasi satu dengan yang lain. Pengertian yang lebih teknis disampaikan oleh Kagermann dkk (2013) bahwa Industri 4.0 adalah integrasi dari Cyber Physical System (CPS) dan Internet of Things and Services (IoT dan IoS) ke dalam proses industri meliputi manufaktur dan logistik serta proses lainnya.

\section{PEMBAHASAN}

\section{Pemasaran Melalui Rantai Pemasaran}

Proses pemasaran diawali dari melihat peluang pasar, melakukan riset pasar, memilih target pasar, menyusun strategi, action dan evaluasi. Namun demikian masih banyak dikalangan usahawan yang tidak melihat tahap-tahap proses tersebut sehingga barang dan jasa yang ditawarkan tidak sampai ke konsumen karena tidak sesuai dengan keinginan dan kebutuhan konsumen pada lokasi tersebut dan juga tidak didukung oleh ruang dan waktu. Pergeseran zaman akan mampu menutupi kekurangan produsen dalam distribusi barang dan jasa melalui jasa yang ada. Keadaan ini akan mendorong produsen untuk meningkatkan kuantitas produksinya karena tidak dibatasi oleh ruang dan waktu. Sistem jasa kini mampu mengantar barang dagangan produsen sesuai tujuan yang diinginkan tanpa ada batas. Menurut Kotler (2005), usaha-usaha untuk memperpendek mata rantai pemasaran/tataniaga adalah salah satu jalan yang dapat membantu usaha bisnis untuk meningkatkan pendapatan. Saluran pemasaran yang terpendek memberikan penerimaan yang terbesar dan resiko pemasaran yang terkecil bagi produsen. Kotler (2005), dalam menyampaikan barang dari produsen ke konsumen melalui saluran pemasaran digambarkan sebagai berikut:

\section{Gambar 1 Arus fisik}

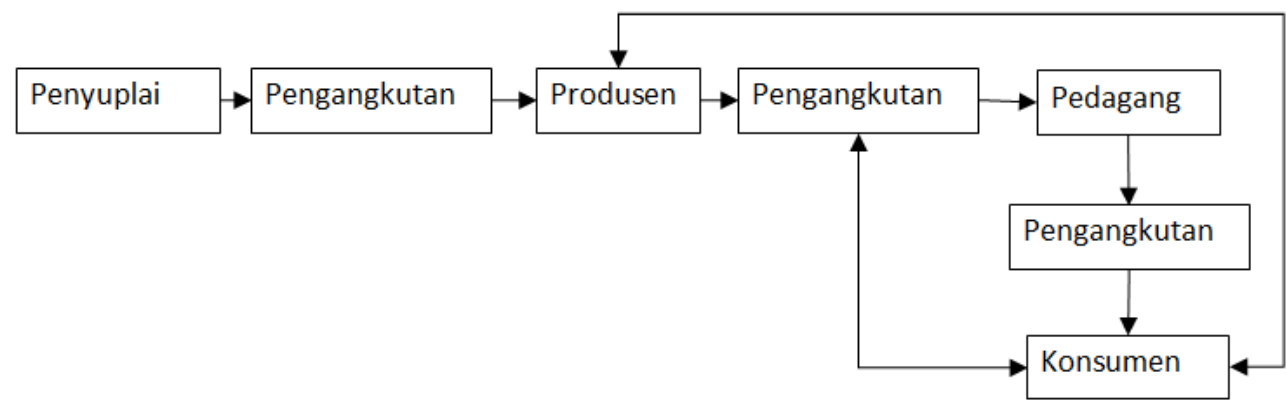

Saluran pemasaran seperti pada gambar 1 di atas menjelaskan tentang gerakan nyata dari produk fisik, mulai dari bahan mentah (suplai/pemasok), 
sampai kepada konsumen terakhir. Saluran pemasaran akan berpengaruh terhadap keputusan produsen terhadap harga yang ditetapkan oleh produsen. Jika rantai saluran pemasaran panjang maka harga sampai ke konsumen akan tinggi begitu juga sebaliknya jika saluran pemasaran pendek maka harga untuk konsumen lebih rendah. Ini bermakna persaingan antar produsen dalam penetapan harga akan semakin bersaing sehingga terjadi kompetisi pasar. Untuk memenangkan kompetisi pasar langkah pertama yang digunakan adalah mencari strategi yang tepat untuk memasarkan hasil produksinya agar mampu bersaing dipasar.

Penentuan strategi ini harus melalui penelitian dan kajian yang mendalam sehingga produksi yang akan dipasarkan akan mampu memenangi kompetisi dan lebih survive. Hal-hal lain yang juga harus lebih diperhatikan dalam strategi marketing adalah berupa penjelasan tentang produk, desain produk, promosi produk, pengiklanan produk, komunikasi kepada konsumen, sampai dengan pengiriman produk agar bisa sampai ke tangan konsumen secara lebih cepat dan tepat. Strategi marketing yang up to date era digitalisasi saat ini menjadikan produsen menjadi semakin lebih dekat dengan kehidupan konsumen sehari-hari. Strategi marketing melalui media digital merupakan langkah yang efektif dan efisien karena rantai saluran pemasaran akan menjadi semakin pendek. Banyak produsen yang membuat suatu produk, tapi tidak menjual secara langsung produknya kepada konsumen akhir (end user), pertimbangan biaya distribusi menjadi faktor utama produsen memilih mendistribusikan produknya sendiri ke konsumen akhir terutama untuk wilayah pemasaran yang belum tercover oleh perusahaan.

\section{UMKM Melalui Sistem Pemasaran}

Kontribusi sektor UMKM terhadap ekspor nasional masih rendah dibandingkan dengan negara lain. Salah satu langkah yang dijalankan oleh pemerintah adalah mendorong kegiatan ekspor produk pelaku usaha mikro kecil dan menengah (UMKM).

\section{Gambar 2 Kontribusi Sektor UMKM Terhadap Ekspor Nasional di Indonesia}

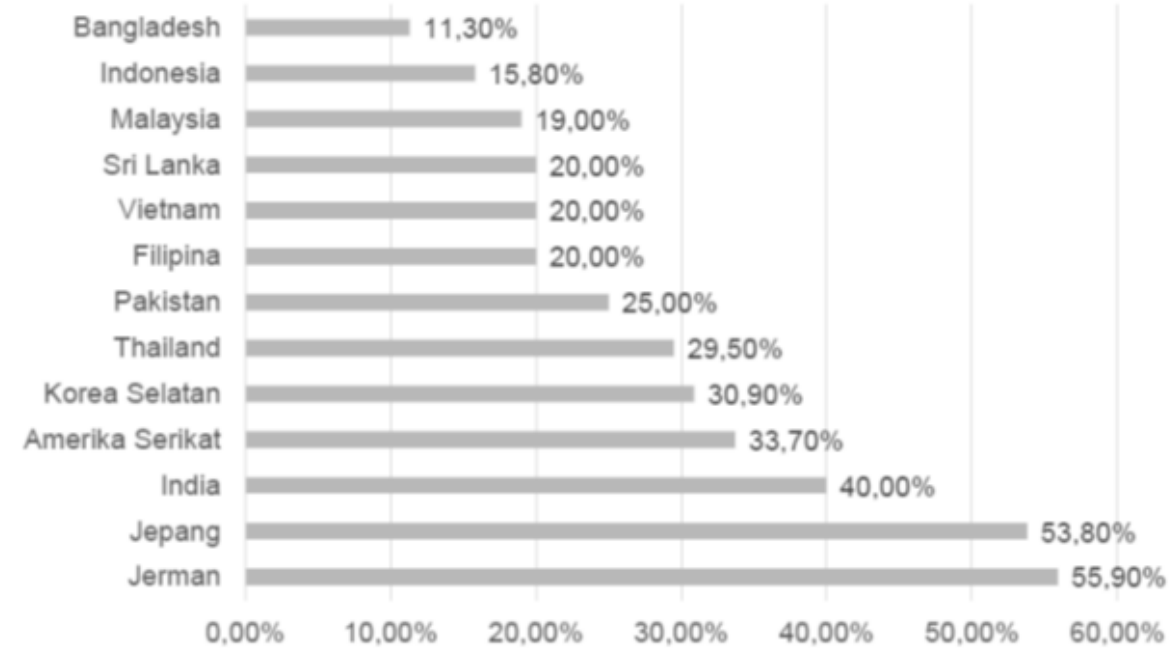

Sumber: (Yoshino dan Wignaraja 2015) 
Berdasarkan gambar 2 di atas bahwa kontribusi UMKM terhadap ekspor nasional masih rendah yaitu sebesar $15.80 \%$ atau sekitar US\$23 miliar dari total ekspor nonmigas. Angka tersebut juga lebih rendah dibandingkan dengan negara Asean lainnya seperti Vietnam 20\% dan Thailand 29.50\%. Keadaan ini menggambarkan bahwa terdapat beberapa indikator pemberdayaan UMKM yang belum berjalan dengan maksimal. Namun demikian hampir 97,2\% UMKM berkontribusi terhadap penyerapan tenaga kerja, ini merupakan angka tertinggi dibandingkan dengan negara Asia lainnya (Yoshino dan Wignaraja 2015). Salah satu dari faktor masih rendahnya kontribusi ekspor nasional adalah masih minimnya pemanfaatan media digital di era digital 4.0.

Indonesia sudah memasuki era Industri 4.0. ini ditandai dengan meningkatnya konektivitas, interaksi antara manusia, mesin dan sumber daya lainnya yang semakin konvergen melalui teknologi informasi dan komunikasi. Menurut McKinsey, ini adalah era digitalisasi sektor manufaktur yang didorong oleh empat aspek: Membanjirnya volume data, kapasitas komputasional, serta konektivitas. Munculnya kapabilitas analitik dan intelijen bisnis. Interaksi baru antara mesin dan manusia seperti sistem realitas tertambah (augmented reality) dan interface. Peningkatan dalam transfer instruksi digital ke dunia fisik seperti pencetak 3D.

Di era digital (Industri 4.0.) ini bisnis harus mengikuti perkembangan zaman agar tetap survive. Tidak hanya teknologi, perdagangan juga harus siap menghadapinya. Bagi usahawan yang menggunakan sistem lama maka besar kemungkinan akan ditinggal oleh pesaing yang lain yang menerapkan sistem terbaru bahkan akan masuk industri-industri asing yang maju dan masuk ke pasar dalam negeri. Berdasarkan riset Wearesosial Hootsuite (Wearesosial 2019), pengguna media sosial di Indonesia mencapai 150 juta atau sebesar 56\% dari total populasi. Jumlah tersebut naik $20 \%$ dari survei sebelumnya. Sementara pengguna media sosial mobile (gadget) mencapai 130 juta atau sekitar $48 \%$ dari populasi. Data ini dapat dilihat seperti pada gambar berikut:

\section{Gambar 3 Pengguna Media Sosial Indonesia}

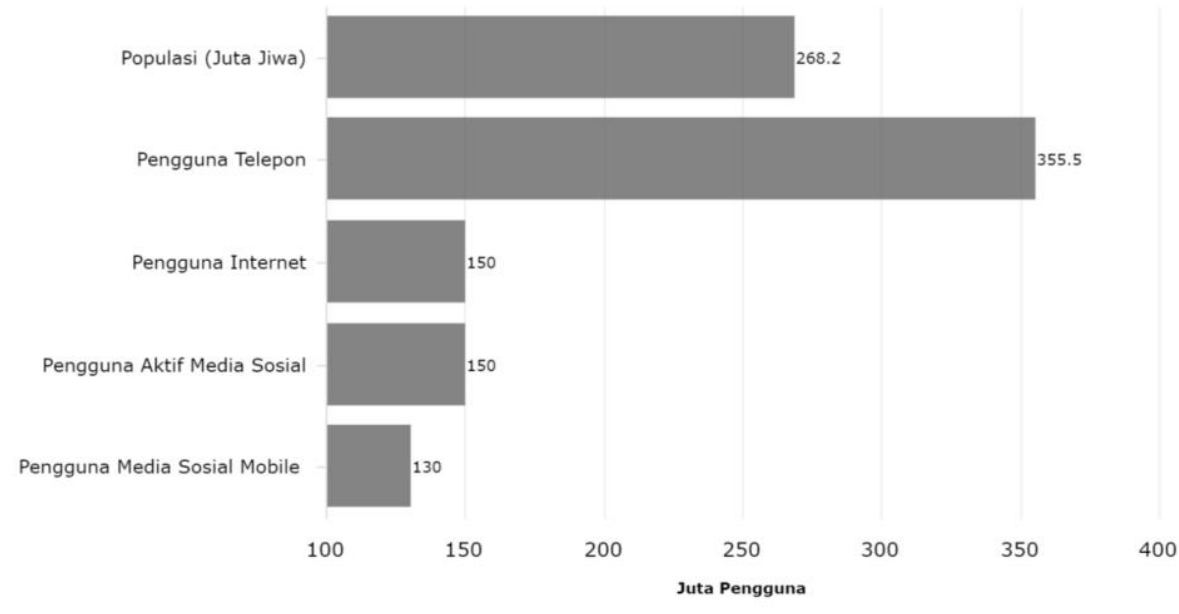

Sumber: (Wearesocial 2019)

Berdasarkan data pada gambar 3 di atas menggambarkan bahwa pesatnya pertumbuhan pengguna internet dan telepon merupakan potensi bagi ekonomi 
digital nasional. Ini merupakan peluang dan tantangan bagi dunia bisnis untuk bersaing dan mendapatkan market share atau pangsa pasar pada masing-masing segmen. Market share merupakan salah satu strategi bisnis yang harus dilakukan oleh setiap bisnis karena market share juga dapat dijadikan sebagai tolok ukur dalam menentukan keberhasilan bisnis dalam menguasai pasar. Strategi bisnis yang tidak efektif akan membawa kerugian bagi pelaku bisnis.

Perkembangan yang pesat terhadap media digital (internet dan media sosial lainnya) ternyata telah menyebabkan media-media lain justru semakin menurun seperti halnya pada media cetak, koran, tabloid dan media radio. Penurunan terhadap berbagai media ini dapat dilihat pada gambar berikut:

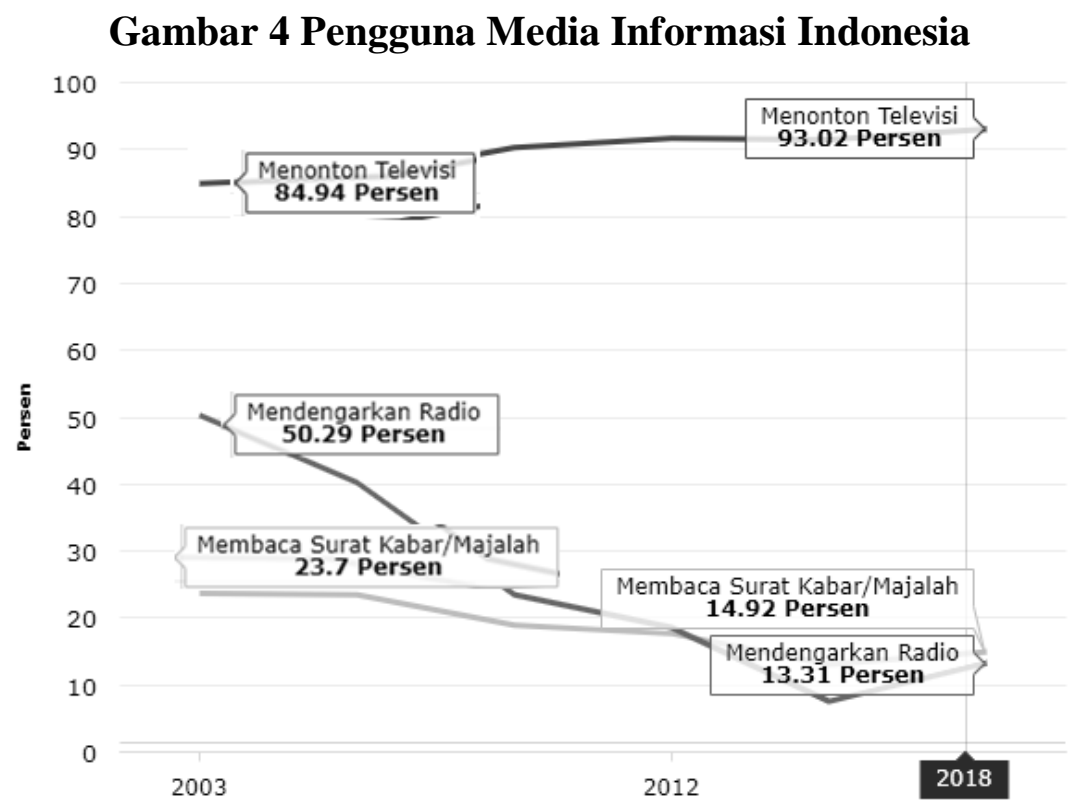

Sumber: Badan Pusat Statistik (BPS), 2019

Berdasarkan hasil survei indikator sosial budaya Badan Pusat Statsitik (BPS), masyarakat (usia 10 tahun ke atas) yang mendengarkan radio dalam seminggu terakhir hanya 13,31\% pada 2018. Angka ini merosot jauh dari 50,29\% pada 2003. Demikian pula masyarakat yang membaca surat kabar atau majalah berkurang menjadi $14,92 \%$ pada 2018 dibanding 23,7\% pada 2003. Adapun masyarakat dalam seminggu terakhir yang menonton televisi justru menunjukkan peningkatan dari 84,94\% pada 2003 menjadi 93,02\% pada 2018.

Gambar 3 dan gambar 4 seperti yang dipaparkan diatas mengindikasikan bahwa kemunculan media online, media sosial serta booming-nya smartphone (telepon pintar) telah menggerus ketertarikan masyarakat terhadap media konvensional seperti surat kabar, majalah/tabloid maupun radio kecuali televisi. Dengan demikian, pemilihan media sebagai alat pemasaran terhadap produk yang dihasilkan merupakan faktor yang dapat dijadikan alasan untuk meningkatkan hasil produksi pada suatu usaha. Berdasarkan hasil penelitian Oztamur dan Karakadilar (2014), UKM di Amerika Serikat dan Turki menunjukan bahwa media sosial saat ini sudah banyak digunakan sebagai alat dalam strategi pemasaran untuk menciptakan value pada pelanggan. Knight (2000) menunjukkan bahwa globalisasi memiliki dampak dan tekanan yang signifikan bagi sektor 
UMKM sehingga para pelaku UMKM harus dapat menerapkan penggunaan teknologi yang tepat guna dan sesuai bagi usaha yang mereka jalankan. Penelitian-penelitian ini menggambarkan strategi pemasaran melalui media digital menjadi keputusan yang tepat untuk memasarkan produk dan jasa yang dihasilkan oleh usahawan.

Wibowo et al. (2015) tentang penerapan strategi pemasaran pada sektor UMKM dengan mengambil studi kasus pada Batik Diajeng Solo menunjukkan bahwa dengan strategi pemasaran yang tepat, yakni dengan memilih segmentasi pasar terfokus pada konsumen organisasi, institusi, dan komunitas dan posisi pasar sebagai produk yang berkualitas dan dapat sesuai dengan pesanan konsumen (customer) serta menggunakan kombinasi bauran pemasaran yang sesuai, seperti perhitungan biaya yang tepat dan sesuai, saluran distribusi baik langsung maupun tidak langsung, termasuk saluran distribusi online maka diperoleh kinerja produk Batik Diajeng Solo yang meningkat sebesar 9.1\% di tahun 2013 dan 59\% di tahun 2014. Knight (2000) menunjukkan bahwa strategi pemasaran memiliki peran yang penting bagi perusahaan untuk membantu menerapkan taktik agar menjadi perusahaan yang sukses. Hasil dari penelitiannya juga menunjukkan bahwa terdapat hubungan yang kuat antara strategi pemasaran dengan penerapan teknologi dan penerimaan terhadap kondisi global.

Dalam hal bauran pemasaran, meskipun produk yang dijual relatif sama dengan yang dijual oleh pesaing mereka, tetapi karena mereka mengedepankan nilai tambah dan diferensiasi maka mereka dapat memberikan produk yang tepat, harga yang layak serta bersaing, pemilihan saluran distribusi yang sesuai, serta pemilihan media promosi yang efektif bagi para pelanggan mereka sehingga kepuasan dan loyalitas pelanggan dapat tercapai. Nory Jones et al. (2015) dengan objek penelitian pada UMKM menemukan bahwa peran dari media sosial bagi pelaku UMKM adalah berikut (1) meningkatkan pengenalan dan rasa ingin tahu konsumen, (2) meningkatkan hubungan baik dengan konsumen, (3) dapat meningkatkan jumlah konsumen baru, (4) meningkatkan kemampuan untuk menjangkau konsumen dalam skala global, dan (5) menambah jalur promosi bagi bisnis local untuk meningkatkan citra UMKM. Damian Ryan (2014) juga menyebutkan beberapa manfaat menjalin hubungan dekat dengan pelanggan, yakni: (1) mendapatkan update informasi dari pelanggan, (2) meningkatkan reputasi profil media sosial perusahaan, (3) menambah sumber informasi selain dari media offline yang dapat digunakan sebagai studi pasar, (4) dapat mempengaruhi influencers untuk ikut pula mempengaruhi para followers-nya sehingga produk kitadapat citra yang baik dan positif.

Dengan demikian, melalui era digital 4.0 kini diharapkan sistem pemasaran sektor UMKM (usaha mikro kecil dan menengah) bisa bersaing dan mampu tumbuh inklusif dan berkelanjutan.

\section{KESIMPULAN}

Terdapat berbagai konsep tentang strategi pemasaran yang diterapkan. Strategi pemasaran secara konvensional di era Industri 4.0 menjadi kurang tepat diterapkan karena terbatas oleh ruang dan waktu. Populasi penduduk Indonesia berjumlah sekitar 268,2 juta jiwa dan sekitar 130 juta atau $48 \%$ dari jumlah tersebut adalah pengguna media sosial mobile. Ini merupakan potensi besar jika 
sistem pemasaran memanfaatkannya dengan maksimal. Usaha mikro kecil dan menengah (UMKM) Indonesia berkontribusi terhadap penyerapan tenaga kerja. Hampir 97,2\% sektor UMKM mampu menyerap tenaga kerja yang ada di Indonesia. Sementara itu kontribuasi ekspor nasional UMKM Indonesia masih rendah bila dibandingkan dengan negara lain. Kontribusi sektor UMKM terhadap ekspor nasional sebesar $15.80 \%$ lebih rendah dari Malaysia 19.00\%, Sri Lanka $20.00 \%$. Salah satu faktor dari rendahnya angka kontribusi tersebut dalam analisis ini adalah masih minimnya para pelaku UMKM menggunakan potensi sumber daya yang ada seperti dengan cara penggunaan media sosial mobile (gadget). Padahal jika potensi ini dimanfaatkan dan dijadikan sebagai salah suatu strategi dalam pemasaran untuk meningkatkan hasil produksi UMKM dengan maksimal sebagai mana yang telah dipraktek pada negara-negara maju, maka hasil produksi akan lebih mudah sampai ke tangan konsumen akhir dengan harga menjadi rendah karena tidak menggunakan rantai pemasaran yang panjang. Dengan demikian melalui era digital 4.0 sistem pemasaran sektor UMKM bisa bersaing dan mampu tumbuh inklusif dan berkelanjutan.

\section{DAFTAR PUSTAKA}

Etzel. Michael J., Walker J.W., Stanton, W.J. 2001. Marketing, Edisi ke-12, New York: Mc Graw-Hill Irwin .

Jones, Nory., Borgman, Richard. dan Ulusoy, Ebru. 2015. Impact of Social Media on Small Business. 22, 611-616.

Knight, Gary. 2000. "Entrepreneurship and Marketing Strategy: The SME Under Globalization". Journal of International Marketing. 8 (2), 12-32.

Kotler, Philip. 2001. Manajemen Pemasaran: Analisis, Perencanaan, Implementasi dan Kontrol. Jakarta: PT. Prehallindo.

Kotler, Philip. 2005. Manajemen pemasaran, Dialih bahasakan oleh Benjamin Molan, buku kedua, edisi kesebelas. Jakarta: PT Indeks.

Kotler, Philip. 2008. Manajemen Pemasaran, Edisi 12 Jilid 2. Jakarta: Indeks.

Mashuri. 2016. "Peran Baitul Maal Wa Tamwil (BMT) Dalam Upaya Pemberdayaan Ekonomi Masyarakat". IQTISHADUNA: Jurnal Ilmiah Ekonomi Kita 5 (2), 114-123.

Oztamur, Dilhan dan Ibrahim Sarper Karakadilar. 2014. "Exploring The Role of Social Media for SMEs: as a New Marketing Strategy Tool for The Firm Performance Perspective". Procedia: Social and Behavioral Sciences. 150, 511-520. Elsevier.

Prasetyo, Hoedi dan Wahyudi Sutopo. 2018. "Industri 4.0: Telaah Klasifikasi Aspek Dan Arah Perkembangan Riset”. J@ti Undip: Jurnal Teknik Industri 13 (1), 17-26.

Ryan, Damian. 2014. Understanding Digital Marketing: Marketing Strategies for Engaging the Digital rd Generation. 3 Edition. London: Kogan Page Limited.

Tambunan, Tulus T.H. 2009. UMKM di Indonesia. Bogor: Ghalia Indonesia.

Tjiptono, Fandy dan Gregorius Chandra. 2011. Service, Quality and Satisfaction (ed 3). Yogyakarta: Andi.

Undang-Undang Republik Indonesia Nomor 20 tahun 2008 tentang UMKM. 
Wearesocial. 2019. Indonesia Digital Landscape: Januari 2019.

Wibowo, Dimas H., Zainul Arifin, dan Sunarti. 2015. "Analisis Strategi Pemasaran Untuk Meningkatkan Daya Saing UMKM (Studi Pada Batik Diajeng Solo)". Jurnal Administrasi Bisnis (JAB). 29 (1), 59-66.

Yoshino, N. P. M., dan Wignaraja, G. 2015. Financial Education in Asia: Assessment and Recommendations. 